\title{
Daubreeia pateraeformis (GERMAR) ZEILLER, A STEPHANIAN SPHENOPSID FROM WESTERN EUROPE AND NORTH AMERICA
}

\author{
Hendrik W. J. VAN AMEROM ${ }^{1}$, William $H$. \\ GILLESPIE ${ }^{2}$ and Robert H. WAGNER \\ ${ }^{1}$ Jos Habetsstraat 30. NL-6419 CD Heerlen, The Netherlands \\ 2916 Churchill Circle. Charleston, WV 25314-1747, U.S.A. \\ ${ }^{3}$ Jardín Botánico de Córdoba. Avda Linneo s/n. 14004 Córdoba, Spain
}

Amerom, H.W.J. van, Gillespie, W.H. and Wagner, R.H. Daubreeia pateraeformis (Germar) Zeiller, a Stephanian sphenopsid from western Europe and North America. [Daubreeia pateraeformis (Germar) Zeiller, una Esfenópsida Estefaniense de Europa Occidental y Norteamérica.] Revista Española de Paleontología, 18 (2), 159-170. ISSN 0213-6937.

\begin{abstract}
Daubreeia pateraeformis (Germar 1844) Zeiller 1888, originally described from the upper Stephanian of the Saale Basin, Saxony (Germany), and the Stephanian B-C of Commentry (Massif Central, France), and recorded subsequently from the Upper Pennsylvanian of West Virginia (USA), and other parts of North America, has most recently been identified from the Stephanian B (sensu Carmaux) of the Ciñera-Matallana Coalfield (province León) in northwestern Spain. This plant megafossil proved to be identical with Kahleria carinthiaca Boersma and Fritz 1984, described from the upper Stephanian of the Kronalpe (Monte Corona) in Carinthia (Austria). It is placed with the Equisetales (laminae incertae sedis). A partial reconstruction is proposed. For the time being, Daubreeia pateraeformis appears to be restricted to Stephanian B-C, including the early Autunian. This plant seems to have favoured a wet habitat.
\end{abstract}

Keywords: Sphenopsida, Equisetales, Carboniferous, Stephanian, Europe, North America.

\section{KURZFASSUNG}

Daubreeia pateraeformis (Germar 1844) Zeiller 1890, ursprünglich beschrieben aus dem Oberstefan vom Saale Becken und dem Stefan B-C des französischen Commentry-Beckens, und danach aus der Monongahela (Ober Pennsylvanium) von West Virginia (USA) und andere Nordamerikanische Fundorte, wurde die Pflanze nun auch im Stefan B (sensu Carmaux) des Ciñera-Matallana Kohlenbeckens (Nordspanien) gefunden. Es stellte sich heraus, dass dieser fossile Pflanzenabdruck identisch ist mit der von Boersma und Fritz (1984) aus dem Oberstefan der Kronalpe (Monte Corona) in Kärnten (Österreich) beschriebene Kahleria carinthiaca. Sie wird den Equisetales (laminae incertae sedis) zugeordnet, und eine Teilrekonstruktion wird vorgeschlagen. Daubreeia pateraeformis ist zur Zeit auf Ablagerungen des späten Stefans einschließlich dem frühen Autun beschränkt. Die Pflanze bevorzugte möglicherweise einen feuchten Standort.

Stichworte: Sphenopsida, Equisetales, Karbon, Stefan, Europa, Nordamerika.

\section{RESUMEN}

Daubreeia pateraeformis (Germar 1844) Zeiller 1890 fue descrita en primer lugar en el Estefaniense Superior de la cuenca de Saale (Sajonia, Alemania), y en el Estefaniense B-C de Commentry (Macizo Central, Francia); posteriormente fue citada en el Grupo Monongahela (Pensilvanico Superior) de Virginia Occidental, así como en otras áreas de EE.UU.; recientemente, también se ha encontrado en el Estefaniense B (sensu Carmaux) de Ciñera-Matallana (León), NO de España. Este fósil vegetal, atribuible a los Equisetales (laminae incertae sedis), 
resulta idéntico a Kahleria carinthiaca Boersma y Fritz 1984, procedente del Estefaniense superior de Kronalpe (Monte Corona) en Carintia (Austria), por lo que debe considerarse como un sinónimo más reciente.

La distribución estratigráfica de Daubreia pateraeformis parece estar restringida al Estefaniense superior (BC), incluyendo el Autuniense inferior. Fianalmente, también se propone una reconstrucción parcial de esta planta que parece haber vivido preferentemente en un medio ambiente húmedo.

Palabras clave: Sphenopsida, Equisetales, Carbonífero, Estefaniense, Europa, Norteamérica.

\section{INTRODUCTION}

During fieldwork in the mid-1960s some intriguing plant fossils were found by the first author in the CiñeraMatallana Coalfield in the province of León, Northwest Spain. These finds, all compressions, were deposited in the collection of the former Geological Survey of The Netherlands (Geologisch Bureau at Heerlen), presently lodged in the National Museum of Natural History "Naturalis" at Leiden (The Netherlands). They were stored with the provisional indication "Aphlebia". However, although there is a superficial resemblance, these plant remains cannot be referred to Aphlebia Presl in Sternberg 1838, which are elements found in the basal part of fern fronds. Neither can they be regarded as Cyclopteris, i.e. large pinnules along the petioles of pteridosperm fronds. For a while, the first author thought that it might be an oversized Schizoneura Schimper and Mougeot 1844 (compare Fig. 5a). Letters and photographs were sent to Dr. K. Asama (July 1970) and Dr. E. Kon'no (July 1971) in order to discuss this idea. However, this identification also had to be rejected and the fossils remained unidentified for the time being.

Photographs were taken in the 1970s by Mr. L.R. Funcken, photographer at the Geological Bureau in Heerlen (The Netherlands). These photographs came to light again, when the first author moved to the Geological Survey of North Rhine-Westphalia at Krefeld (Germany) in 1992. Confronted again with these photographs a striking resemblance to Kahleria carinthiaca Boersma and Fritz 1984 was noted. When consulting with the third author, three additional specimens from Ciñera-Matallana came to light. These specimens are in the Palaeobotanical Collections of the Botanical Garden of Córdoba (Spain). This brings the number of specimens from Ciñera-Matallana (Stephanian B) up to six. They all belong to the medium sized leaf type. When discussing the identity in Charleston (U.S.A.) with the second author in June 1996, it became clear that Kahleria Boersma and Fritz 1984 is a synonym of Daubreeia Zeiller 1888/1890, a genus recorded most recently by Gillespie and Clendening (1966) from the upper Pennsylvanian of West Virginia. Indeed, the second author had already noted the identity between Kahleria and Daubreeia shortly after Kahleria had been published as a new genus, and advised Dr. Boersma accordingly in private correspondence. In the present paper the entire material available from America, Spain (and France) is described and reinterpreted.

\section{SYSTEMATICS}

\author{
CLASS SPHENOPSIDA Scott 1909 \\ ORDER EQUISETALES Trevisan 1876 \\ (laminae incertae sedis) \\ Genus Daubreeia Zeiller 1888/1890
}

Type species: Daubreeia pateraeformis (Germar 1844) Zeiller 1890

\section{Daubreeia pateraeformis (Germar 1844) Zeiller 1890 \\ Figs 1-8}

1844 Aphlebia pateraeformis: Germar, 5-6, Taf. II, figs 1-2 (see

Fig. 1).

1844 Aphlebia patens: Germar, 7-8, Taf. III (see Fig. 2).

1888/1890 Daubreeia pateraeformis: Zeiller, 10-15, pl. XLI, fig.

1 (see Fig. 3).

? 1896 Daubreeia biondiana: Arcangeli, 65-69.

? 1903 Daubreeia biondiana: Barsanti, 12, 33, 36.

1908 Daubreeia pateraeformis: Sellards, 430-433, pl. LII, figs

1-2, pl. LV, fig. 4, pl. LVI, fig. 5, pl. LVIII, fig. 1.

1966 Daubreeia pateraeformis: Gillespie and Clendening, 167,

pl. 3, fig. 4, pl. 4, figs 1-2, pl. 5, figs $1-2$ (p. 163-165).

1974 Daubreeia species 1: Blazey, 7, 14, pl. 10, fig. 35.

1980 Cyclopteris species: Fritz und Boersma, 236-237, Abb. 20.

1984 Kahleria carinthiaca: Boersma und Fritz, 177, 188, Abb.1-

9 (see our Fig. 4).

1990 Kahleria carinthiaca: Fritz und Boersma, 44, Abb. 101 (99)

(same specimen as for Abb. 2 in Boersma und Fritz, 1984).

2001 Daubreeia pateraeformis: Van Amerom und Kabon, 48, Tafn 1-4.

Description: Leaves, sometimes rather large, consisting of fused aggregates of laminae with a raised midrib and rectilinear to slightly curved lateral single veins. The larger leaves show sometimes a regular alternation of stronger and weaker secondary veins, giving the lamina a surface pattern of small vaulted bars. The veins are placed at an acute angle to the midrib. They are strongly marked in the lower part, and are more closely spaced. The midrib, relatively thick at the point of attachment, gradually thins towards the rim of the leaf. The laterally fused laminae are sometimes divided by more or less deep incisions. They are between 8 and $20 \mathrm{~cm}$ long and possess indistinct but apparently entire margins, which are sometimes torn. At the base of the leaf a more or less central point of attachment is found, whereas in one case the laminae are attached around a "hollow" stem, about $30 \mathrm{~mm}$ wide. 


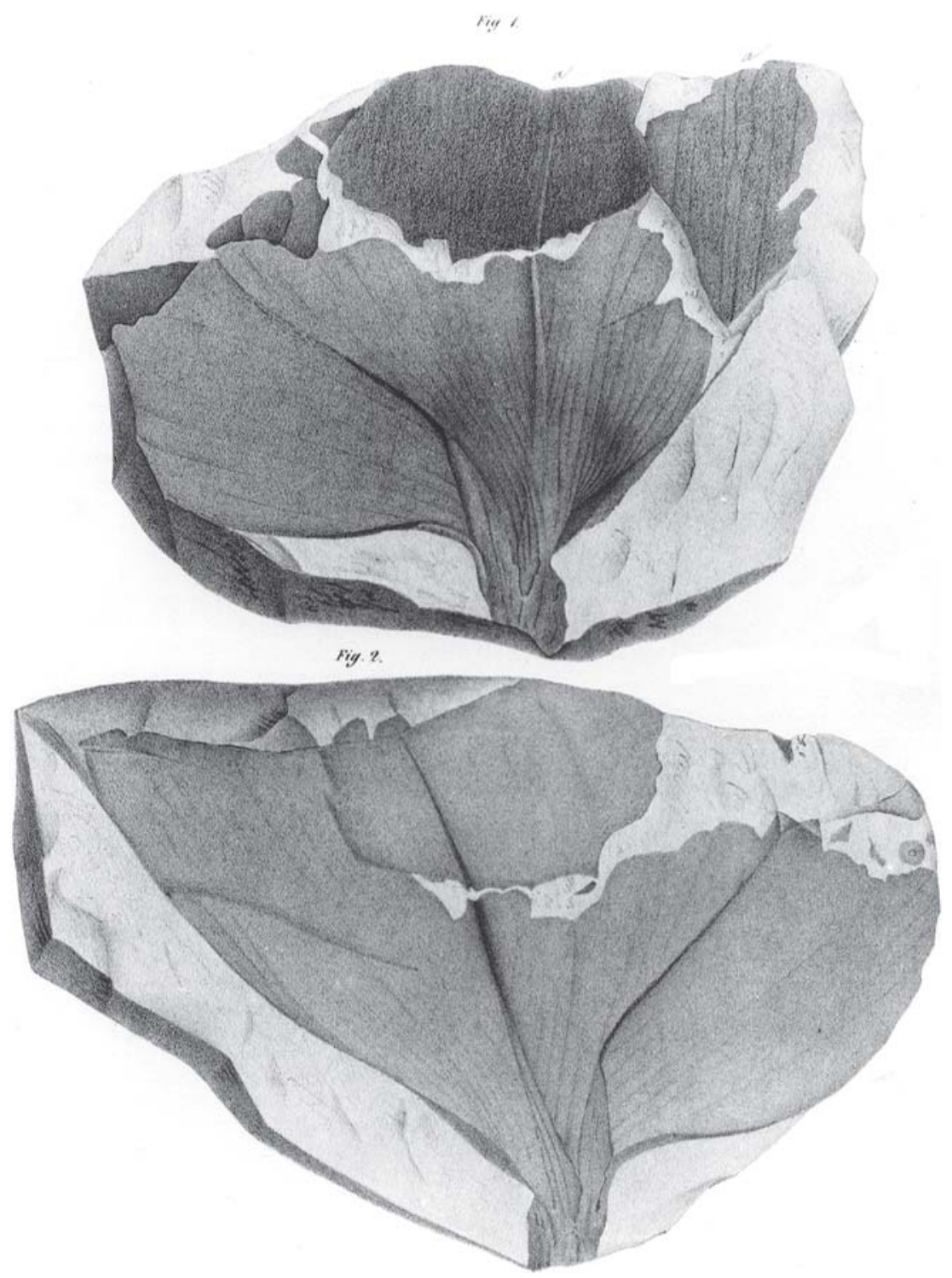

Figure 1. Aphlebia pateraeformis Germar 1844. After Taf. II, figs 1, 2 published by Germar (1844), reduced by one half. It shows a specimen (part and counterpart) with rather large composite leaves from the side, having a conical shape and a narrow base. About $21 \mathrm{~cm}$ wide. From Wettin and Löbejün, Saale Area, Saxony, Germany.

Discussion: Zeiller (1888/1890) introduced the genus Daubreeia for certain Cyclopteris-like leaves, which were originally described by Germar (1844) under the name Aphlebia. The illustration was published first (1888) (see Fig. 3 of the present paper), and the text later (1890). Within this genus he included Aphlebia pateraeformis Germar 1844 (our Fig. 1) and Aphlebia patens Germar 1844 (our Fig. 2), which he regarded as corresponding to one and the same species. Presently, the genus Daubreeia comprises two species: Daubreeia biondiana Arcangeli 1896 and D. pateraeformis (Germar 1844) Zeiller 1888/1890 (cf. Jongmans and Dijkstra, 1959; Dijkstra and Van Amerom 1982). Daubreeia biondiana was published without illustration, and Arcangeli's description is rather confusing, it being unclear which is the difference from the type species. The first author attempted tracing the material on which Arcangeli based his description, but failed. Prof. C. Venturini, who kindly tried to find the missing fossils, suggested in a letter that they might have been lost. In the absence of new information on Daubreeia biondiana, it should probably be regarded as species dubia.

Observation of the available material of Daubreeia pateraeformis shows that there are mostly four laterally fused laminae per leaf, but occasionally there are only three, whereas the larger leaves are sometimes composed of five to six laminae. Each leaf apparently constitutes a wide sheath, which seems to be arranged around a thin axis or, in one significant specimen, around a wide hollow stem. A good deal of distortion of the original conical shape seems to have taken place during fossilisation. Preservation is usually three-dimensional, probably be- 


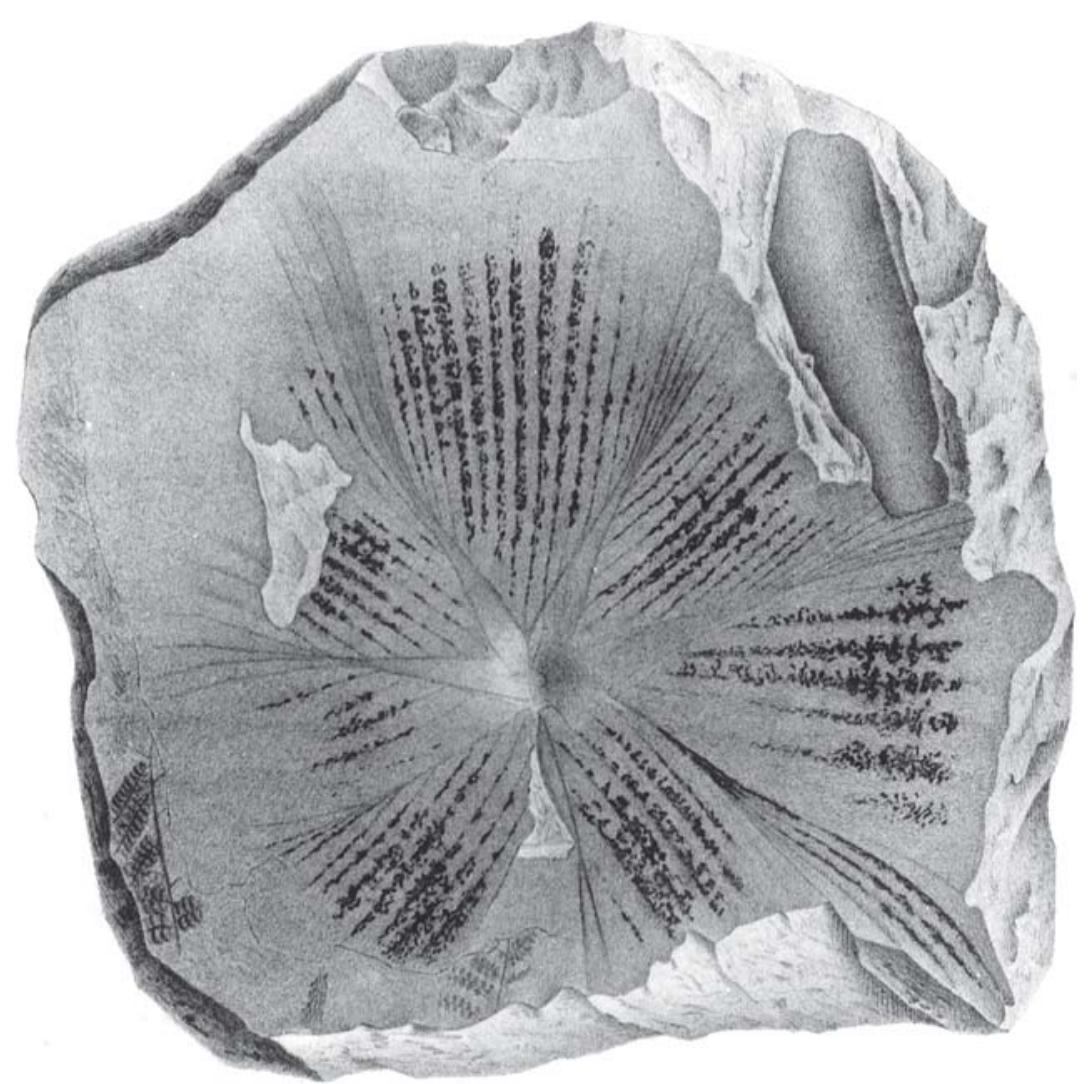

Figure 2. Aphlebia patens Germar 1844. After Germar (1844) Taf. III, reduced by one half. The specimen is seen from above. Rims damaged and partly missing. About $20 \mathrm{~cm}$ wide. From the "Philipper Halde" (= coal tip), Wettin, Saale Area, Saxony, Germany.

cause the leaves were enrolled. The enrolled margins often break off when the specimen is recovered from the rock. These observations suggest that both the smaller and the larger leaves were of rather delicate tissue.

Comparing the material from West Virginia and Spain (Figs 5,6) with the illustrations of five specimens described by Boersma and Fritz (1984) from the Kronalpe (Monte Corona) in Austria under the name of Kahleria carinthiaca Boersma and Fritz 1984, it is clearly apparent that these fossils are identical with Daubreeia pateraeformis. The second author, when observing the published figures of Kahleria almost twenty years ago, immediately noticed the striking similarity with Daubreeia. He accordingly informed Dr. Boersma, but his letter went unanswered. The only indication that this letter was actually received, appeared in the remark by Boersma and Fritz (1990, p. 142) that "Verwandte Gattungen von Kahleria (Dolerophyllum, Daubreeia) nur aus (dem ) Ober-Stefan bekannt (sind)".

The specimen on our Fig. 5a shows a certain resemblance to Calamariophyllum stockmansii (Vetter 1968) Langiaux 1984. The veins combined with a prominent relief in the lower part of the leaf provide a vague resemblance to the narrow leaflets composing the leaves of Equisetites Sternberg 1833. Vetter (1968) described large leaves comparable in size to the material in hand, from the upper Stephanian of Decazeville in the Massif Central, France, and attributed them to the genus Equisetites. Langiaux (1984) felt uneasy with this attribution because these remains did not really fit the well established genus Equisetites based on the more complete specimens of Equisetites muensteri Sternberg 1833 from Keuper and Rhaetian beds, which were closely comparable to the extant genus Equisetum Linné. He therefore used the available genus Calamariophyllum Hirmer 1927 for these isolated leaf composites, to which he joined several other species of similar type, as Hirmer (1927) had done as well, i.e. Calamariophyllum (Poacites) zeaeforme (Schlotheim 1820), C. vaujolyi (Zeiller 1892), and C. spatulatus (Zeiller 1895). [Compare Jongmans and Dijkstra (1969), and Dijkstra and Van Amerom (1995)]. Aspasia amplectens De Stefani (1901) from the lower Permian of Monte Vignale in Tuscany, Italy, should also be assigned to Calamariophyllum. The resemblance of one of our specimens (Fig. 5a) to Calamariophyllum and the calamitean character of the stem of Kahleria in Boersma and Fritz (1984, Abb. 8), i.e. our Fig.4, caused the first author originally to attribute Kahleria to Calamariophyllum stockmansii and thus to the Articulatae (Dijkstra and Van Amerom, 1996: 339). However, Vetter's and Lan- 


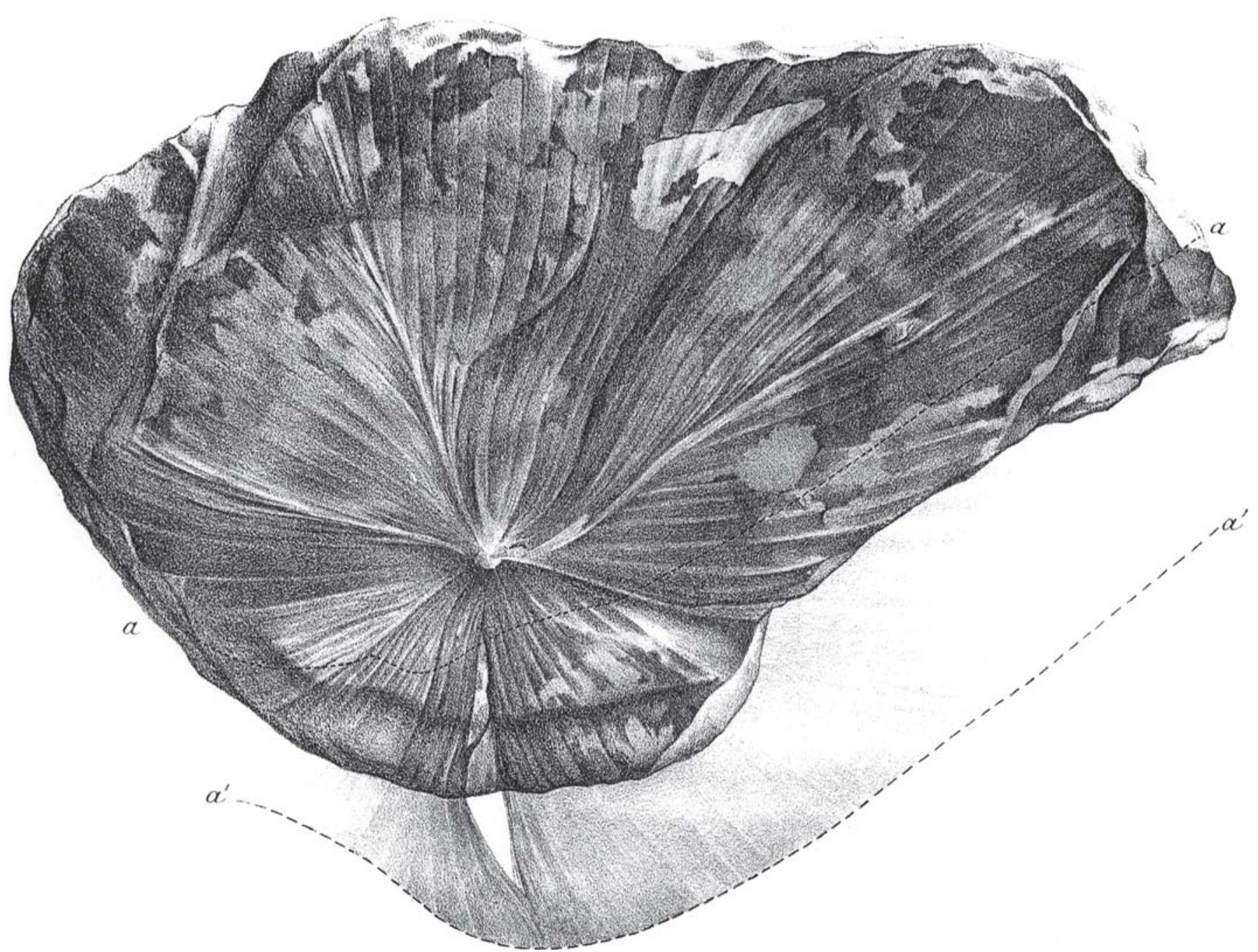

Figure 3. Daubreeia pateraeformis (Germar 1844) Zeiller 1890. After Zeiller (1888), pl. XLI, fig. 1. The specimen is seen from the underside. Natural size. From the Commentry Coal Basin, Massif Central, France.

giaux's illustrations of Calamariophyllum stockmansii show rather incomplete specimens which cannot be reasonably identified with Kahleria (= Daubreeia).

Vetter (1968) compared his finds with Equisetites spatulatus Zeiller 1895 and E. zeaeformis (Schlotheim 1820) Andrä 1850. However, Equisetites spatulatus is quite different, having rounded leaves. Equisetites zeaeformis differs from Calamariophyllum stockmansii in having less fused leaves. They are separate over a more considerable length, and they are also smaller. Much larger than the specimens at hand but comparable in habit, is Calamariophyllum crassinervium (Sandberger 1864) Hirmer 1927. This species shows up to $28 \mathrm{~cm}$ long leaf composites with a fused, pointed top. One of Sandberger's specimens has been reexamined and refigured by Vogellehner (1967). Van Amerom et al. (1997) synonymised Kahleria with Daubreeia, and attributed this genus to the Equisetales (laminae incertae sedis). The attribution to the Equisetales is supported by the apparent habitat of this plant, which seems to have lived in a wet environment.
Localities and palaeoenvironment of Daubreeia: The specimens from the Austrian Kronalpe (Locality 12 of Boersma and Fritz 1990), were found in silty shales of the Auernig Formation. This formation comprises sediments deposited during a late Stephanian transgressive phase. According to Krainer (1990), Daubreeia (al. Kahleria) belongs to a autochthonous vegetation on the shore of a marine basin. The plant remains were deposited without much transport. New finds from a nearby locality as reported by Van Amerom and Kabon (2001) suggest a special environment, probably lagoonal. The records from Ciñera-Matallana in Northwest Spain are from silty shales in several different formations corresponding to fluviatile and swamp deposits, laid down in the non-marine part of a coastal basin. The species found in West Virginia were mainly obtained from roof shales of the Pittsburgh Coal in the Fairfax Stone opencast site of Grant and Tucker Counties (Gillespie and Clendening, 1966). Additional remains from the roof shales of the Pittsburgh Coal were found in Pennsylvania. One specimen was collected from the Cassville Shale near 


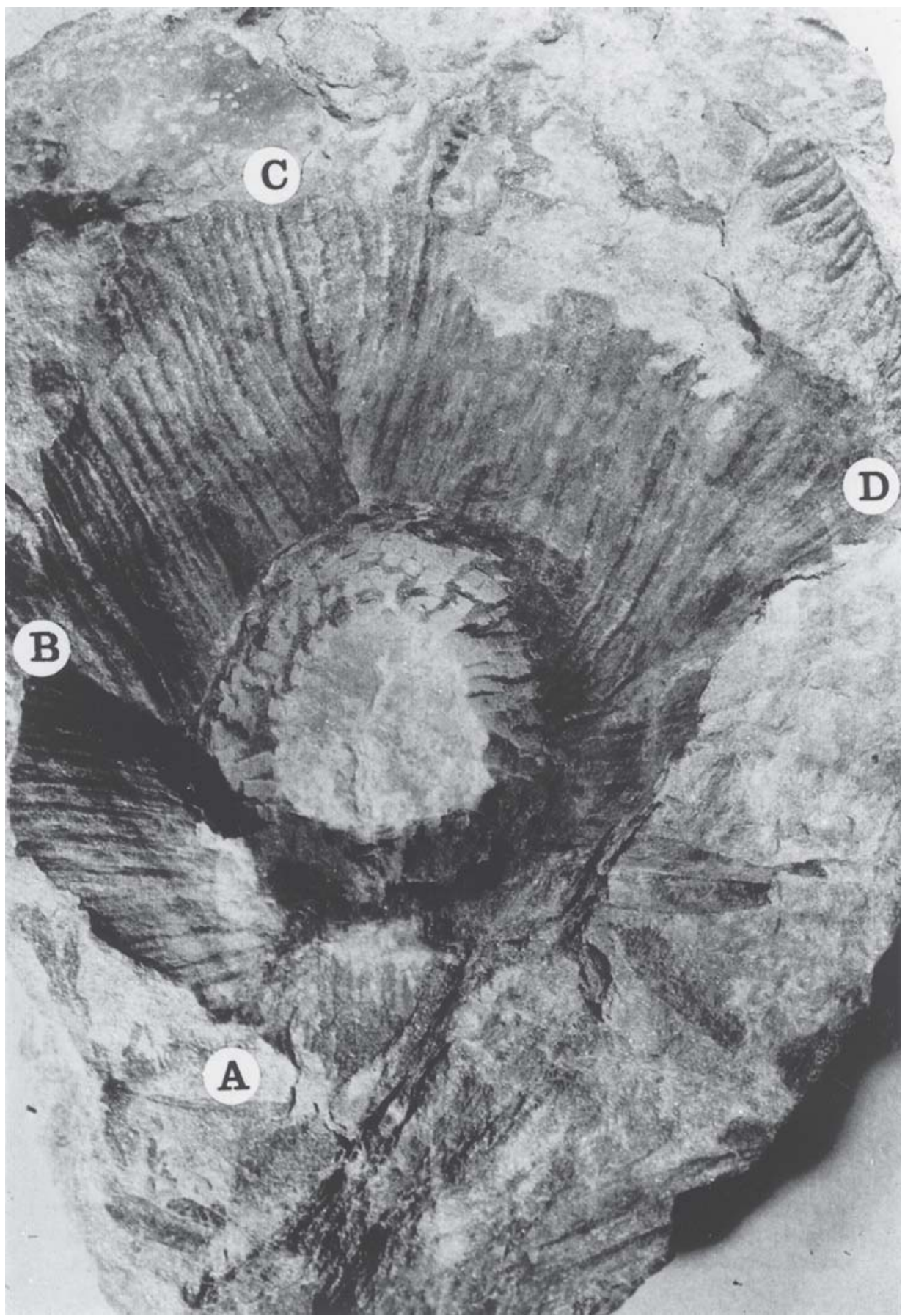

Figure 4. Kahleria carinthiaca Boersma and Fritz 1984. After Abbildung 8 in Boersma and Fritz (1984). Specimen showing large fused leaves (A-D), attached to a hollow stem. Natural size. From the "Krone" locality, Kärnten, Austria.

Figure 5. Daubreeia pateraeformis (Germar 1844) Zeiller 1890.

a. Medium sized single leaf fragment. Natural size. Coal tip near Llombera, Ciñera-Matallana, Province León, Spain, (Van Amerom loc. 9L).

b. Medium sized fused leaves, quadripartite, seen from underneath, margins torn and demaged. Natural size. CiñeraMatallana, Province León, Spain, (Van Amerom loc. 9L).

c. Fragment of medium sized fused leaves. Natural size, Valle Tabliza, Llombera Syncline, Bienvenidas Formation, lower part, Province León, Spain. (Wagner loc. 1567).

d. Medium sized fused leaves, seen from underneath, Coal tip near Llombera, Ciñera-Matallana, Province León, Spain, (Van Amerom loc. 5L).

e and f. Fragment of medium sized quadripartite fused leaves, with damaged margins. Part and counterpart. Natural size. Borehole 43, 349.50 m depth, San José Formation, between coals 4 and 5, Ciñera-Matallana, Province León, Spain, (Wagner loc.4646). 

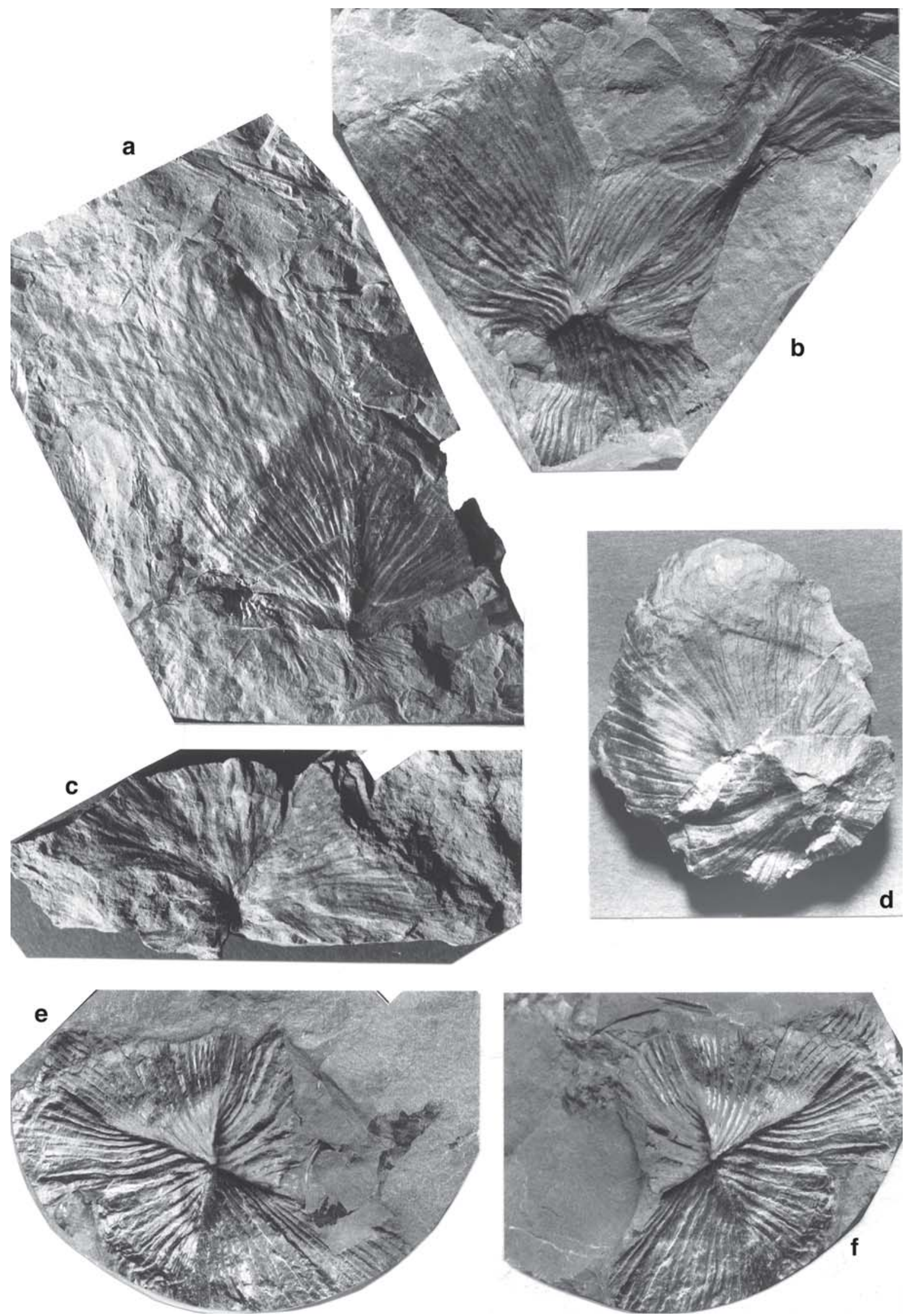

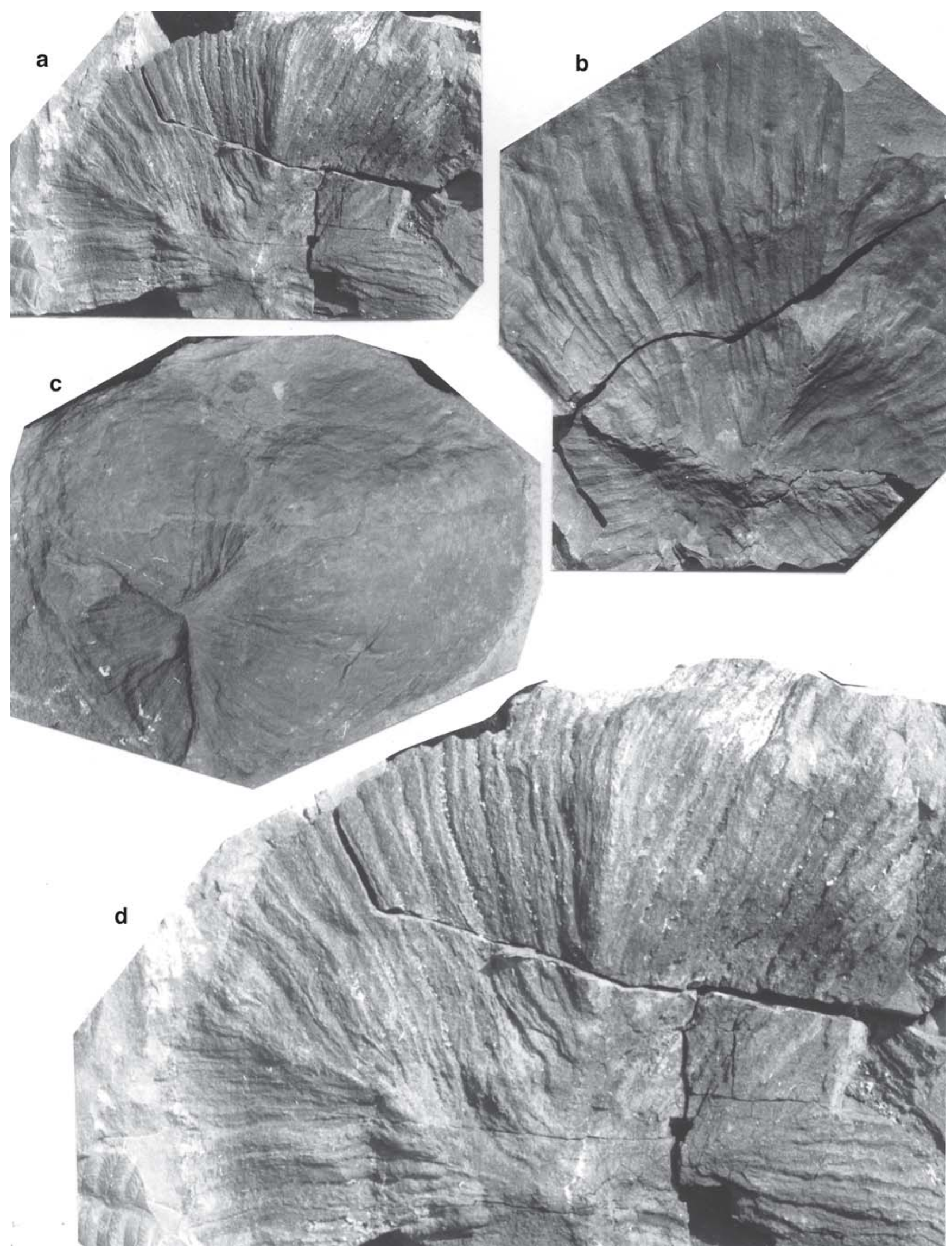
Cassville, West Virginia (Gillespie and Clendening, 1966). All seem to have been deposited under wet but low energy conditions. The specimens from Kansas came from the Elmdale Formation at Onaga (White, 1903) and Reece (Sellards, 1908). Moreover, Sellards (1908: 465) reported Daubreeia pateraeformis from the Douglas Formation, Le Roy and Lawrence shales. Altogether, it seems that Daubreeia pateraeformis occurs in coastal, fluviatile and drowning swamp facies.

Affinity of Daubreeia: The correct attribution of these leaves to a particular taxon is inhibited by the fact that the stems to which they were attached are generally missing. When discussing his Aphlebia pateraeformis, Germar (1844) saw in the lowermost basal part of the specimen a fragment of the stem (our Fig. 1). This stem would have been $15 \mathrm{~mm}$ wide. However, his plates do not show clearly where the leaf ends and where the stem begins. The specimen published by Boersma and Fritz (1984, Abb. 8) is perhaps the most interesting with regard to stem attachment (compare our Fig. 4). Being apparently unaware of the significance of this specimen, Boersma and Fritz (1984) compared with Cyclopteris Brongniart 1828, Doleropteris Grand'Eury 1877 , Aphlebia Presl in Sternberg 1838, and Dolerophyllum Saporta 1878, which they all regarded as different. The present writers concur: there is no morphological identity. These remains are also of quite different affinity. Doleropteris and Aphlebia are both applied to fern remains. Cyclopteris belongs to the pteridosperms, and Dolerophyllum is attributed to a number of different taxa, such as Cordaites, pteridosperms (especially Medullosales) and primitive gymnosperms (Jongmans and Dijkstra, 1960). Boersma and Fritz (1984) did not see the resemblance with sphenopsid taxa, and failed to compare with Daubreeia Zeiller.

Abbildung 8 in Boersma and Fritz (1984) shows that the leaves of Daubreeia pateraeformis (i.e. their Kahleria carinthiaca) were attached to "hollow" stems in the middle of the leaf composite. This may be considered characteristic of Sphenopsida. The apparent sheaths, the Calamariophyllum-like appearance of the laminae and the "hollow" stem suggest that Daubreeia belongs to the Equisetales.

Remarks to the proposed reconstructions (figs 7 and 8): Based on all the available material it seems that the most common form is of a quadripartite nature and generally of medium size. Larger leaves were illustrated by Germar (1844, Tafn II-III). His specimen of Taf. II, figs 1-2 (part and counterpart), seen from the side, shows a conical shape (our Fig. 1), whereas his Taf. III depicts a horizontally compressed specimen, which probably comprised six fused leaves (our Fig. 2). Zeiller (1888, pl. XLI fig. 1) published a large horizontally compressed specimen, showing six fused leaves (our Fig. 3). The larger leaf of Boersma and Fritz (1984, Abb. 8) shows the base of a leaf whorl near the point of attachment to a "hollow" stem. This leaf whorl is quadripartite. These characteristics are synthesised in Figures 7 and 8 of the present paper. As is shown in Figs 6a, c and d, herein, the laminae show sometimes a regular pattern of stronger and weaker secondary veins, as is indicated in the reconstruction of Fig. 8. Not quite clear is the kind of attachment of these leaves to the axis. Zeiller (1890) thought that the leaf whorls might have been terminally placed on a axis, but none of the available fossils seems to warrant this interpretation.

Figure 7 shows the supposed aspect of a medium-sized leaf whorl, attached to a delicate axis. Figure 8 shows a larger leaf whorl, attached to a calamitean-like stem, which may have had its position in a more basal part of the plant. Since some of the essential information is missing, a reconstruction showing the connection of both leaf types might be regarded as fiction and has therefore not been attempted.

\section{LOCALITIES AND STRATIGRAPHIC AGE}

Western Europe: Daubreeia pateraeformis (Germar 1844) Zeiller 1890 is recorded here from the Ciñera-Matallana Coalfield (province León): this remains the only part of Northwest Spain where it has been seen. The Ciñera-Matallana Coalfield is attributed to Stephanian B (Wagner, 1971, 1983), or more precisely, Stephanian B sensu Carmaux (see Wagner 1998). Localities are as follows: Van Amerom loc. 5L, 9L: San José Formation, coal tips near Llombera. Wagner loc. 1567: Pastora Formation, at $2100 \mathrm{~m} \mathrm{NW}$ of Aviados. Wagner loc. 4646: San José Formation, at $52.50 \mathrm{~m}$ above Seam 5, Borehole 43, depth 349.50 m. Wagner loc. 9549: Bienvenidas Formation, lower part, Tabliza Valley, northern flank of Llombera Syncline.

In France, Daubreeia was initially recorded from the Commentry Basin in the Massif Central. It has also been seen in the Blanzy Basin (Massif Central) by Dr. M. Krings (written communication from Prof. J.H.F. Kerp). Both basins are attributed to the upper Stephanian (B-C).

Figure 6. Daubreeia pateraeformis (Germar 1844) Zeiller 1890.

a. Fragment of a somewhat larger quadripartite specimen, seen from underneath. Natural size. Roof shales of the Pittsburgh coal (Monongahela Formation), Fairfax Stone opencast site in Grant and Tucker Counties, West Virginia, U.S.A. (Gillespie Coll.)

b. Fragment of a somewhat larger quadripartite specimen, horizontally embedded in the sediment. Natural size. Same locality as above.

c. Quadripartite specimen, seen from underneath. Note strongly marked midribs. Natural size. Same locality.

d. Same as Fig. 1, x 2. Note pattern of thinner and thicker veins. 


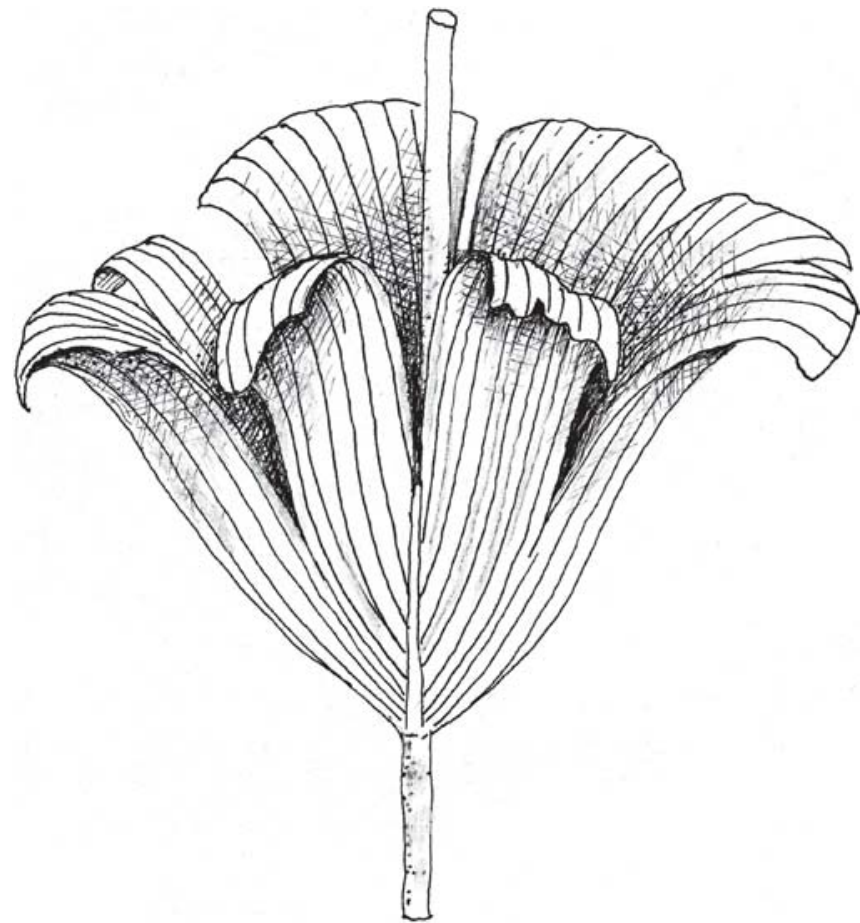

Figure 7. Suggested reconstruction of a medium sized composite leaf of Daubreeia pateraeformis (Germar 1844) Zeiller 1890. Based mainly on Fig. 5a.

The types figured by Germar (1844), are from the upper Stephanian of Wettin-Löbejün in the Saale region, Saxony, Germany.

The finds in Carinthia (Austria) from the Kronalpe (Monte Corona) are referred to as "Upper Carboniferous", which means a general Stephanian age, by Boersma and Fritz (1984), and Fritz and Boersma (1990); as well as Fritz (1990), and attributed to "Upper Stephanian" by Boersma and Fritz (1990).

North America: In West Virginia Daubreeia pateraeformis is reported as occurring occasionally in the roof shales of the Pittsburgh coal (basal Monongahela Formation/Group) in the Fairfax Stone area of Grant and Tucker counties and also, with one specimen only in the Cassville Shale (basal Dunkard Group) near Cassville, West Virginia (Gillespie and Clendening, 1966). In Pennsylvania, several specimens were found in the roof shales of the Pittsburgh coal near Burgettstown, several miles west of Pittsburgh (Miklausen, 1949). From Kansas, Sellards (1908) and White (1903) mentioned the genus from the Lawrence Shale (lower Virgilian, probably equivalent to Monongahela of the Appalachians). Also from Kansas, a single specimen was mentioned by Cridland et al. (1963) from the top of the Stranger Formation (probably equivalent to the Conemaugh of the Appalachians). Blazey (1974) recorded Daubreeia from probable lower Permian (or Upper Pennsylvanian) strata in Arizona. The Conemaugh and Monongahela formations are currently attributed to Stephanian C /lower Autunian (Wagner and Lyons 1997).

\section{CONCLUSION}

Daubreeia is a rare, Stephanian B-C/early Autunian floral element in the Amerosinian palaeoequatorial belt. It may be attributed to the Equisetales and corresponds to a wet low energy environment.

\section{ACKNOWLEDGEMENTS}

The authors thank Professor C. Venturini (Dipartimento di Scienze Geologiche, Univ. Bologna, Italy) for his attempt to find the original material of Daubreeia biondiana Arcangeli, and Professor J.H.F. Kerp (Univ. Münster, Germany) for his remarks on the genus Daubreeia. Mrs B. Hüskes is acknowledged for producing the photographs. Comments from the referees, Drs C. Diéguez and J.B. Diez, proved most helpful.

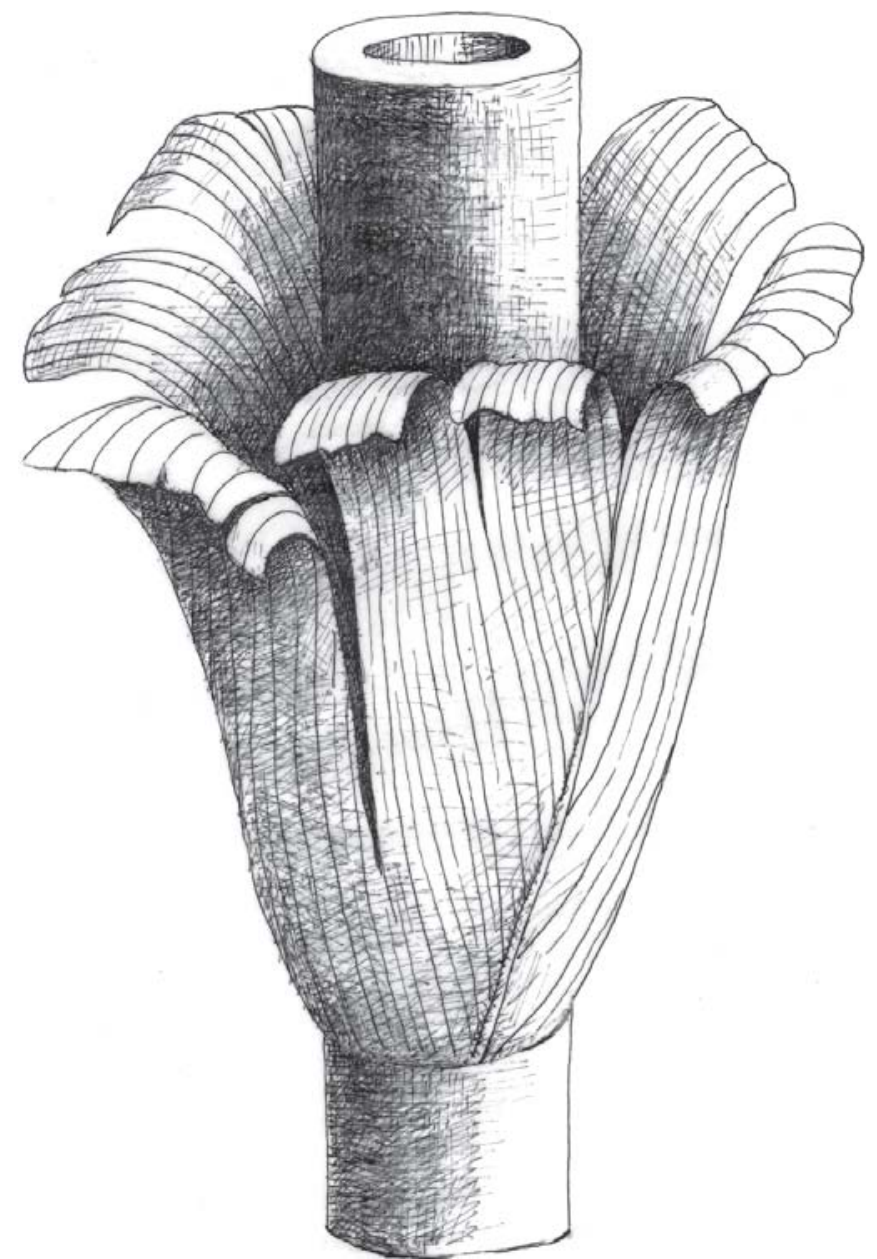

Figure 8. Suggested reconstruction of a larger specimen. Based on Abbildung 8 published by Boersma and Fritz (1984) and additional remains. 


\section{REFERENCES}

Amerom, H.W.J. van und Kabon, H. 2001. Neue DaubreeiaFunde in Kärnten (Österreich). Wulfenia, 8, 47-59.

Amerom, H.W.J. van, Gillespie, W.H. und Wagner, R.H. 1997. Daubreeia pateraeformis, eine neue Charakterpflanze des mittleren Stefans bis untersten Autun im euramerischen Raum. Symposium Paläontologische Forschungen C. Ettingshausen, p. 5 (Abstract).

Andrä, C.S. 1850. Verzeichniss der in dem Steinkohlengebirge bei Wettin und Löbejün vorkommenden Pflanzen. Jahresberichte des naturwissenschaftlichen Vereines in Halle, 118.

Arcangeli, G. 1896. Sopra due fossili d'Iano. Bolletino Società Botanica Italiana, 5, 65-69.

Barsanti, L. 1903. Contribuzione allo studio della flora fossile di Iano. Atti Società Toscana di Scienze Naturali, 19, 336.

Blazey, E.B. 1974. Fossil flora of the Mogollon Rim, Central Arizona. Palaeontographica, Abt. B, 146 (1-2), 1-20.

Boersma, M. und Fritz, A. 1984. Kahleria carinthiaca nov. gen., nov spec. (incertae sedis) aus Stefan-Schichten der Kronalpe (Kärnten, Österreich). Carinthia II, 174./94 Jahrgang, 177-188.

Boersma, M. und Fritz, A. 1990. Die Paläofloren Kärntens: Oberkarbon/Unter Perm. Carinthia II, 180./100 Jahrgang, (49 Sonderheft), 133-172.

Brongniart, A. 1828. Prodrome d'une Histoire des Végétaux fossiles. 225 p. Paris. F.G. Levrault.

Cridland, A.A., Morris, J.E. and Baxter, R.W. 1963. The Pennsylvanian plants of Kansas and their stratigraphic significance. Palaeontographica, Abt. B, 112 (1-3), 5892.

Dijkstra, S.J. und Amerom, H.W.J. van 1982. Fossilium Catalogus, II: Plantae, Pars 89, Kugler Publications, Amsterdam, 145-292.

Dijkstra, S.J. und Amerom, H.W.J. van 1995. Fossilium Catalogus, II: Plantae, Pars 96, Kugler Publications, Amsterdam, 1-156.

Dijkstra, S.J. und Amerom, H.W.J. van (1996): Fossilium Catalogus, II: Plantae, Pars 97, Kugler Publications, Amsterdam, 157-345.

Fritz, A. 1990. Stratigraphisch-floristischer Rückblick. Carinthia II, 180./100 Jahrgang, (49. Sonderheft), 173180.

Fritz, A. und Boersma, M. 1980. Pflanzliche Grossreste aus dem Oberkarbon der Krone, Karnische Alpen. Carinthia II, 170./90 Jahrgang, 221-238.

Fritz, A. und Boersma, M. 1990. Die steinkohlenzeitliche Pflanzenwelt Kärntens in ihrer fossilen Überlieferung. Carinthia II, 180./100 Jahrgang, (49. Sonderheft), 15-108.

Germar, E.F. 1844. Die Versteinerungen des Steinkohlengebirges von Wettin und Löbejün im Saalkreise, bildlich dargestellt und beschrieben, Erstes Heft [von Sieben], Schwetschke's Verlag, Halle, 1-12.

Gillespie, W.H. and Clendening, J.A. 1966. West Virginia Plant Fossils, I. Dolerotheca and Daubreeia. Proceedings West Virginia Academy of Science, 38, 159-168.
Grand'Eury, F.C. 1877. La flore carbonifère du Département de la Loire et du centre de la France, étudiée aux trois points de vue botanique, stratigraphique et géognostique. Mémoires Académie des Sciences, Institut de France, XXIV (2 ${ }^{\mathrm{e}}$ Série), $624 \mathrm{pp}$.

Hirmer, M. 1927. Handbuch der Paläobotanik. Band I: Thallophyta. Bryophyta. Pteridophyta. R. Oldenbourg Verlag, München und Berlin, 708 pp.

Jongmans, W.J. und Dijkstra, S.J. 1959. Fossilium Catalogus, II: Plantae, Pars, 39, (12), 941-1038, 's-Gravenhage.

Jongmans, W.J. und Dijkstra, S.J. 1969. Fossilium Catalogus, II: Plantae, Pars, 75, 1-106, 's-Gravenhage.

Krainer, K. 1990. Zur faziellen Entwicklung pflanzenfossilführender Oberkarbon- und Unterpermsedimente Kärntens. Carinthia II, 180/100. Jahrgang, 109-132.

Langiaux, J. 1984. Flores et faunes des formations supérieures du Stéphanien de Blanzy-Montceau (Massif Central francais), Stratigraphie et Paléoécologie. Revue périodique de «La Physiophile», Société Etudes Sciences Naturelles et Historiques de Montceau-les-Mines, 60, Supplement au No. 100, 270 pp.

Miklausen, A.J. 1949. A contribution to the fossil flora of the roof shales of the Pittsburgh coal bed of southwestern Pennsylvania. (Unpublished Ph.D. thesis, University of Pittsburgh, Pa), 200 pp.

Saporta, G. de 1878. Sur le nouveau groupe paléozoïque des Dolerophyllées. Comptes rendus Académie des Sciences, Paris, LXXXVII.

Sellards, E.H. 1908. Fossil Plants of the Upper Paleozoic of Kansas, In: The University Geological Survey of Kansas, (Special Paper on Oil and Gas), IX, 386-480.

Stefani, C. de 1901. Flore Carbonifere e Permiane della Toscana. Pubblicazioni del Real Istituto di Studi Superiori Pratici e di Perfezionamento, Sezione di Scienze Fisiche e Naturali, 212 pp.

Sternberg, K. von 1820-1838. Versuch einer geognostischbotanischer Darstellung der Flora der Vorwelt. I (18201825) - 1 (1820): 1-24, Tafn I-XIII; 2 (1823): 1-33, Tafn XIV-XXVI; 3 (1824): 1-40, Tafn XXVII-XXXIX; 4 (1825): 1-48, Tafn XL-LIX, Tafn A-E. II (1833-1838) 5/6 (1833): 1-80, Tafn I-XXVI; $7 / 8$ (1838, Presl): 81-220, Tafn I-LXVIII, Tafn A-B, (incl. Corda: Skizzen zur vergleichenden Phytotomie vor- und jetztweltlicher Pflanzenstämme, I-LXXI).

Vetter, P. 1968. Géologie et paléontologie des Bassins houillers de Decazeville, de Figeac et du Détroit de Rodez. I. Description géologique, 442 pp., 11 pls. II. Étude paléontologique, 194 pp., 49 pls. Houillères du Bassin d'Aquitaine, Albi.

Vogellehner, D. 1967. Die Flora des Stefans an der Hohengeroldseck bei Lahr (Mittlerer Schwarzwald) I. Sphenophyta (Sphenophyllales und Equisetales). Berichte Naturforschende Gesellschaft, Freiburg im Breisgau, 57, 133168.

Wagner, R.H. 1971. The stratigraphy and structure of the Ciñera-Matallana Coalfield (prov. León, N.W. Spain). Trabajos de Geología, 4, 385-429.

Wagner, R.H. 1983. The palaeogeographical and age rela- 
tionships of the Portuguese Carboniferous floras with those of other parts of the western Iberian peninsula, In: The Carboniferous of Portugal. Lemos de Sousa, M.J. and J.T. Oliveira (Eds.). Memórias Serviços Geológicos de Portugal, 29, 153-177.

Wagner, R.H. 1998. Consideraciones sobre los pisos de la Serie Estefaniense. Monografías Academia de Ciencias Exactas, Físicas, Químicas y Naturales de Zaragoza, 13, 9-19.

Wagner, R.H.. and Lyons, P.C. 1997. A critical analysis of the higher Pennsylvanian megafloras of the Appalachian region. Review Palaeobotany and Palynology, 95 (1-4), 255-283.
White, D., 1903. Summary of fossil plants recorded from the Upper Carboniferous and Permian formations of Kansas. In: Stratigraphy and Paleontology of the Upper Carboniferous rocks of the Kansas section. Adams, G.E., Girty, G.H. and White, D. U.S. Geological Survey Bulletin, 211, 85-117.

Zeiller, R. 1888/1890. Études sur le terrain houiller de Commentry. Flore fossile. Première Partie, Texte (1890): 366 pp.; Atlas (1888): 42 pls., St. Etienne.

Zeiller, R. 1895. Note sur la flore des gisements houillers de la Rhune et d'Ibantelly (Basses-Pyrénées). Bulletin Société géologique de France, (3), 23, 482-489.

Manuscrito recibido: 4 de diciembre, 2002 Manuscrito aceptado: 26 de mayo, 2003 